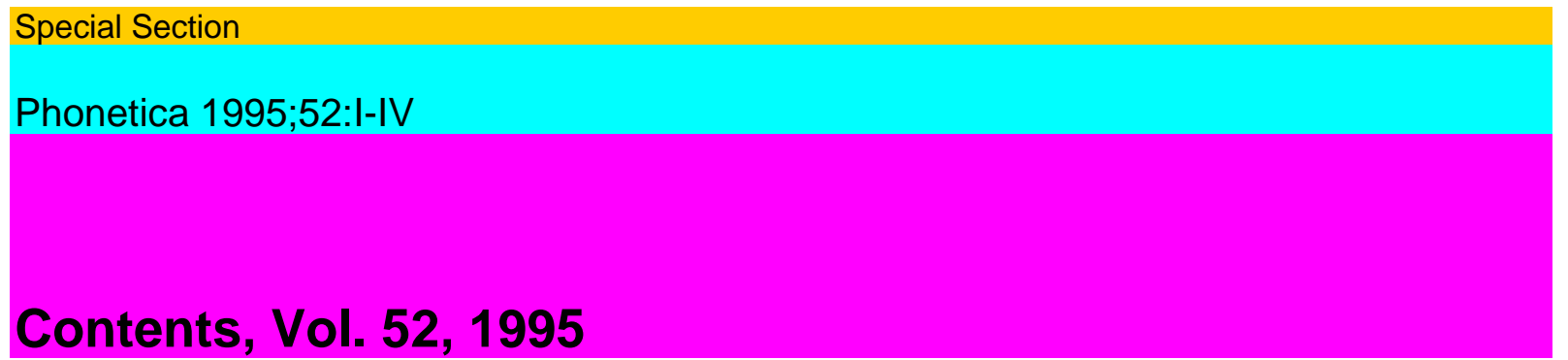

\title{
Contents Vol. 52,1995
}

No. 1

No. 3

Original Paper

Phonetics of Intervocalic Consonant Perception: 1

Retrospect and Prospect

Pickett, J.M.; Bunnel, H.T.; Revoile, S.G.

Effects of Speaking Rate Changes on Native and 41 Nonnative Speech Production Schmidt,

A.M.; Flege, J.E.

Libri 55

Publications Received for Review 59

No. 2

Original Paper

Lengthening in Verb-Gapped Constructions 61

Berkovits, R.

Effects of Focus Distribution, Pich Accent and 71 Lexical Stress on the Temporal Organization of Syllables in Dutch Sluijter, A.M.C.; van Heuven, V.J.

Native Speakers of Spanish Show Rate-Depen- 90 dent Processing of English Stop Consonants Flege, J.E.; Schmidt, A.M.

Libri 112

Publications Received for Review 113

Time for Speech

Festschrift on the Occasion of Klaus Kohler's 60th Birthday

Editors' Introduction 121

Simpson, A.; Barry, W.J.

Phonetic Explanations for Cross-Linguistic Pro- 123 sodic Similarities Vaissière, J.

Feature, Phoneme, Syllable or Word: How Is 131

Speech Mentally Represented? Sendlmeier, W.F.

Kleine Phonetik und Große Phonetik 144

Tillmann, H.G.

A Probable Case of Clicks Influencing the Sound 160 Patterns of Some European Languages

Ohala, J.J.

Phonetic Interpretation of the Word Accent Con- 171 trast in Swedish Engstrand, O.

Interactions of Fundamental Frequency Contour 180 and Perceived Duration in Norwegian van

Dommelen, W.A.

Effect of Fundamental Frequency on Medial 188

[+Voice] I [-Voice] Judgments Diehl, R.L.; Molis, M.R.

Determination of Glottal Excitation Cycles in 196 Running Speech Hess, W.J. 
Vowel-Vowel Production: The Distinctive 205

Region Model (DRM) and Vowel Harmony Carre, R.; Bourdeau, M.; Tubach, J.-P.

Danish Vowels - Surface Contrast versus 215

Underlying Form

Grønnum, N.

Explaining the Dispersion of the Single-Vowel 221 Occurrences in an F1/F2 Space Iivonen, A. 111

Schwa vs. Schwa $+/ \mathrm{r} /$ in German 228

Barry, W.J.

An Interactive Technique for Matching Speaker 236

Identity

Carlson, R.; Granström, B.

Phonetic and Phonological Aspects of English 242

Affricate Production in Children with Speech

Disorders

Hardcastle, W.J.; Gibbon, F.; Scobbie, J.M.

The Acoustic Parameters of Polish Voiceless

Fricatives: An Analysis of Variance Jassem, W.

Syllable Structure and Dorsal Friction in German 259 Simpson, A.

Index autorum 262

No. 4

Original Paper

The Place of Articulation Distinction in Voiced 263 Oral Stops: Evidence from Burst Spectra and Formant Transitions Cassidy, S.; Harrington, J.

C-Centers Revisited 285

Byrd, D.

Variability of Lip and Jaw Movements in the

Speech of Children and Adults Smith, B.L.

Index autorum 317

Publications Received for Review 318

IV

Contents 